\title{
Autumn migration routes and wintering areas of juvenile Chinese Egrets (Egretta eulophotes) revealed by GPS tracking
}

\author{
Zhijun Huang ${ }^{1}$, Xiaoping Zhou' ${ }^{1}$, Wenzhen Fang ${ }^{1 *}$, Hailong Zhang ${ }^{2}$ and Xiaolin Chen ${ }^{1 *}$ (D)
}

\begin{abstract}
Background: The vulnerable Chinese Egret (Egretta eulophotes) is a long-distance migratory waterbird whose migration and wintering information is poorly understood. This study aims to identify the autumn migration routes and wintering areas of juvenile Chinese Egrets and determine the migration movement traits of this species.

Methods: Thirty-nine juvenile Chinese Egrets from the Fantuozi Island, an uninhabited offshore island with a large breeding colony of Chinese Egrets in Dalian, China, were tracked using GPS/GSM transmitters. Some feathers from each tracked juvenile were collected for molecular identification of sex in the laboratory. The GPS locations, recorded at 2-h intervals from August 2018 to May 2020, were used for the analyses.

Results: Of the 39 tracked juveniles, 30 individuals began their migration between September and November, and 13 successfully completed their autumn migration between October and November. The juveniles migrated southward via three migration routes, coastal, oceanic and inland, mainly during the night. The migration duration, migration distance, flight speed, and stopover duration of the 13 juvenile egrets that completed migration averaged $5.08 \pm 1.04$ days, $3928.18 \pm 414.27 \mathrm{~km}, 57.27 \pm 5.73 \mathrm{~km} / \mathrm{h}$, and $23.08 \pm 19.28 \mathrm{~h}$, respectively. These juveniles wintered in the coastal wetlands of Southeast Asia including those in the Philippines, Vietnam, and Malaysia, and only one successfully began its spring migration in June 2020.

Conclusions: This study newly finds that the oceanic route taken by juvenile Chinese Egrets, suggesting that the juveniles are able to fly over the Pacific Ocean without a stopover. Moreover, our novel data indicate that coastal wetlands along the East Asian-Australasian Flyway are important areas for both autumn migration stopover and the wintering of these juveniles, suggesting that international cooperation is important to conserve the vulnerable Chinese Egret and the wetland habitats on which it depends.
\end{abstract}

Keywords: Autumn migration routes, Egretta eulophotes, GPS tracking, Juvenile bird, Wintering area

\section{Background}

Seasonal climatic changes and food availability fluctuations drive many species of animals to migrate between breeding and wintering areas (Alerstam et al. 2003;

\footnotetext{
*Correspondence: wzfang@xmu.edu.cn; xlchen@xmu.edu.cn ${ }^{1}$ Key Laboratory of the Ministry of Education for Coastal and Wetland Ecosystems, College of the Environment and Ecology, Xiamen University, Xiamen 361102, China

Full list of author information is available at the end of the article
}

Newton 2008; Rappole 2013). For inexperienced juveniles, their long-distance migration is incredibly challenging (Klaassen et al. 2014; Oppel et al. 2015; Rotics et al. 2016; Vega et al. 2016) regardless of whether they travel by themselves (McKinnon et al. 2014) or follow adults (Sergio et al. 2014; Hewson et al. 2016; Meyburg et al. 2017). Juveniles may have migration strategies that differ from those of adults (Strandberg et al. 2010; McKinnon et al. 2014), such as choosing different movement patterns (Oppel et al. 2015), spending more time

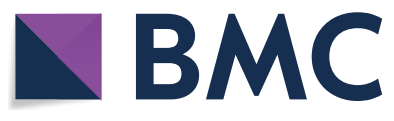

(c) The Author(s) 2021. Open Access This article is licensed under a Creative Commons Attribution 4.0 International License, which permits use, sharing, adaptation, distribution and reproduction in any medium or format, as long as you give appropriate credit to the original author(s) and the source, provide a link to the Creative Commons licence, and indicate if changes were made. The images or other third party material in this article are included in the article's Creative Commons licence, unless indicated otherwise in a credit line to the material. If material is not included in the article's Creative Commons licence and your intended use is not permitted by statutory regulation or exceeds the permitted use, you will need to obtain permission directly from the copyright holder. To view a copy of this licence, visit http://creativecommons.org/licenses/by/4.0/. The Creative Commons Public Domain Dedication waiver (http://creativeco mmons.org/publicdomain/zero/1.0/) applies to the data made available in this article, unless otherwise stated in a credit line to the data. 
at stopover sites (Mellone et al. 2013), flying with large flocks to escape predators, or exploring new migration paths to accommodate environmental change (Yoda et al. 2017). Although the juvenile migration and wintering destination of several ardeid species have been examined (Jourdain et al. 2008; Geary et al. 2015), further conservation studies addressing the juvenile migration ecology of other species, especially those that are either threatened or depend on particular areas, are still needed (Rotics et al. 2016; Vega et al. 2016).

The Chinese Egret (Egretta eulophotes) (Pelecaniformes: Ardeidae) is a globally vulnerable species with an estimated population below 10,000 worldwide (BirdLife International 2020). It is a wetland-dependent bird, usually foraging in coastal wetlands, mainly breeding on offshore islands in eastern China, North Korea, South Korea and eastern Russia, and wintering in coastal regions of southeast Asia, with sightings of banded bird occurring in the Philippines, Indonesia, Malaysia, Singapore, Brunei, Vietnam and Thailand. This egret is a long-distance migrant, likely migrating through coastal South Korea, Japan and China. According to the IUCN, the Chinese Egret has suffered population reductions in recent decades because of the reclamation of tidal mudflats, estuarine habitats, and offshore breeding islands for agriculture and industry (BirdLife International 2020). Although many studies have focused on the breeding behavior, feeding ecology and genetics of the Chinese Egret (Zhou et al. 2010; Huang et al. 2013; Wang et al. 2013; Dai et al. 2015; Lei et al. 2016), and juvenile Chinese Egret migration data were collected from within China from 5 transmitters (Zhang et al. 2018), the transnational migration and wintering areas of this vulnerable species have not been studied.

In this study, we documented the transnational migration and wintering areas of juvenile Chinese Egrets and aimed to: (1) identify and map juvenile Chinese Egret autumn migration routes with Global Positioning System (GPS) tracking, (2) determine their migration movement traits such as travel distance, migration duration, stopover duration and flight speed, and (3) identify their wintering areas. Our novel juvenile Chinese Egret migration data will provide a fundamental basis for further studies on the population dynamics and habitat conservation of this vulnerable species.

\section{Methods}

\section{Study area}

Juvenile Chinese Egrets were captured on Fantuozi Island $\left(39^{\circ} 9^{\prime} 12.16^{\prime \prime} \mathrm{N}, 122^{\circ} 18^{\prime} 19.84^{\prime \prime} \mathrm{E}\right)$ in Dalian, Liaoning Province, China (Fig. 1). This offshore island is located in the Yellow Sea and near Bohai Bay, and its distance from the mainland is approximately $11.9 \mathrm{~km}$. Fantuozi Island has hosted a large breeding colony of vulnerable Chinese Egrets during April to October in recent years. The area of this breeding island is approximately $0.09 \mathrm{~km}^{2}$ and the island is uninhabited.

\section{Capture of birds and transmitter attachment}

In August 2018, 39 fully flighted juvenile Chinese Egrets were captured on the ground near their nests at night using a hand-held net after they fledged, their weights and body length were measured, and some feathers were collected to extract DNA to unambiguously assign sex later in the laboratory (Huang et al. 2013). Then, the juveniles were fitted with solar-charged GPS/GSM transmitters (HQB-2512S, weight $14 \mathrm{~g}$, or HQB-2009P, weight 9 g; Hunan Global Messenger Technology, China). The weight of the transmitter plus backpacks with a Teflon ribbon harness was approximately $2-4 \%$ of the average egret's weight $(449.10 \pm 43.21 \mathrm{~g})$ (Hadjikyriakou et al. 2020). Both types of transmitters included a solar panel with rechargeable batteries, transmitting data at 2-h intervals via the GSM network. All birds were released within $2 \mathrm{~h}$ at the site of capture when no abnormal behavior or death was observed after transmitter attachment.

\section{Migration parameters}

Departure was considered to have occurred when new locations showed a significant southern movement and directional movements continued to occur (Huschle et al. 2013). The wintering area was based on the IUCN document or determined by both movements not continuing to move south and juveniles surviving through whole wintering period in the reached area during DecemberFebruary to ensure that the data represent the locations of wintering birds. When a juvenile arrived at a wintering area, its autumn migration was considered complete. The autumn migration of juvenile Chinese Egrets was defined as the last point recorded from the vicinity of its natal island before departure until the first point reached in the wintering area, and using the WGS-84 (World Geodetic System 1984, used by all GPS devices) coordinate system, the migration distance was calculated by summing all the distances of consecutive migration locations between these two points, not including the variation in locations at stopover sites ( $\mathrm{Li}$ et al. 2020). A stopover site was defined as an area when the speed was $0 \mathrm{~km} / \mathrm{h}$ and where a juvenile stayed for at least $4 \mathrm{~h}$ (two GPS positions and intervals recorded with a transmitter) during the migration journey (Mi et al. 2018; Alonso et al. 2020). The inland and coastal migration routes indicated that more than two thirds of the juvenile stopover sites occurred in freshwater and coastal wetlands, respectively. Migration duration was defined as the total duration between the last date in the vicinity of the natal island 


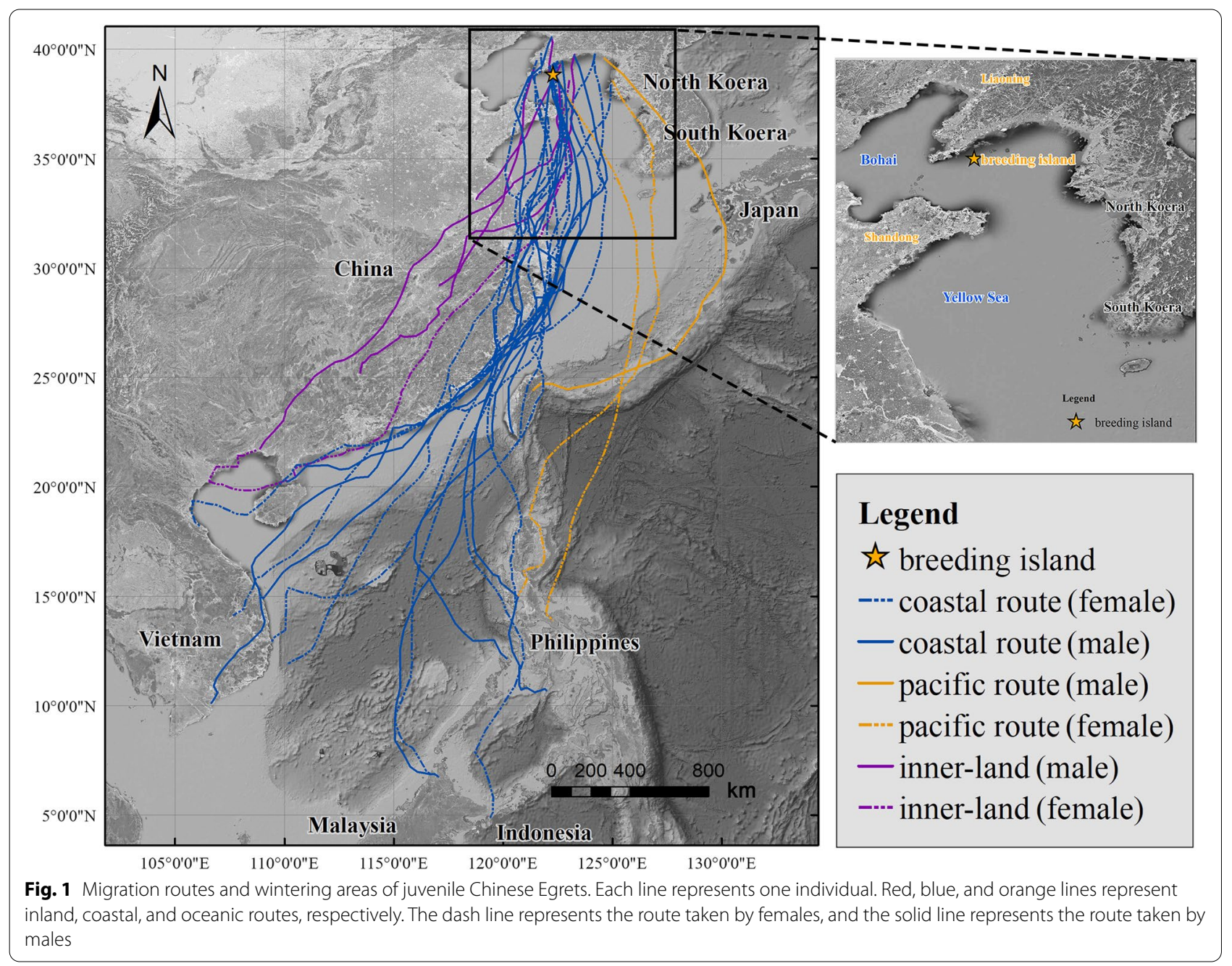

before departure and the first date on which successfully arriving individuals reached the wintering area, including the periods spent at stopover sites (Huschle et al. 2013). Migration speed was calculated as the migration distance divided by the migration duration (Monti et al. 2018; Li et al. 2020). Night and day were defined as 6:00 p.m. to 6:00 a.m. and 7:00 a.m. to 5:00 p.m. Beijing time, respectively, depending on the transmitter's transmission at 2-h intervals via the GSM network and according to the closer local times of sunrise and sunset (https://richu rimo.51240.com/or www.timeanddate.com) in October in two time zones, UTC +8 (China, Philippines, and Malaysia) and UTC +7 (Vietnam), in which the juvenile Chinese Egrets passed during their autumn migration.

The death of a tracked juvenile was identified on the basis of three indicators (Monti et al. 2018; Sergio et al. 2019): the transmission data indicated that the transmitter was functioning normally, GPS locations confirmed that the transmitter was stationary or the juvenile was not moving, and terminal temperature values followed the environmental temperature fluctuations. However, this indirect death identification sometimes cannot be distinguished from transmitter loss and hence might overestimate the mortality of juveniles. Therefore, the retrieval of carcasses or transmitters in the field was used to further confirm death and determine the cause of death if possible. Transmitter-failure (signal loss) was assumed to occur when the GPS signal was suddenly interrupted and no new GPS data were further received. This transmitter-failure identification procedure sometimes included death that occurred over the sea, as no carcass or transmitter could be found, and hence might underestimate mortality.

\section{Data analyses}

GPS positions were utilized to map the migration routes of the juvenile Chinese Egrets, visualize their movements with Google Earth remote-sensing images (Google Inc. 2013), and identify their wintering areas (Klaassen et al. 2010; Page et al. 2014; Hadjikyriakou et al. 2020) 
via ArcGIS 10.3. A-test was used to analyze gender differences and all statistical analyses were conducted in $\mathrm{R}$ 3.5.1 (R Core Team 2018).

\section{Results}

\section{Tracking results}

Thirty-nine juvenile Chinese Egrets were captured and tracked in the summer of 2018, including 15 females and 24 males. During their first autumn journey, migration information was obtained for 30 tracked juveniles (14 females, 16 males), and 9 tracked juveniles ( 1 female, 8 males) died before starting migration (Table 1). Finally, 13 tracked juveniles ( 8 females and 5 males) successfully finished migration and arrived in the wintering area, 13 tracked juveniles unfortunately failed, and 4 lost signals during migration.

\section{Migration routes}

The juvenile Chinese Egrets departed southward from the vicinity of their natal island and underwent directional movements that continued to occur in a narrow range, with longitude ranging between $128.39^{\circ} \mathrm{E}$ and $105.76^{\circ} \mathrm{E}$ and latitude ranging from $40.55^{\circ} \mathrm{N}$ to $4.71^{\circ}$ N. GPS tracking data showed that the juvenile Chinese Egrets migrated via three routes: coastal, inland, and oceanic (Fig. 1).

The coastal route was most often used by the juvenile Chinese Egrets. Twenty-one of the tracked egrets (11 females, 10 males) migrated along this route, with 11 individuals successfully arriving in the wintering area. The juveniles flew along the eastern coast of Chinese mainland, passed across the Taiwan Strait and South China Sea, and finally arrived in their wintering area. On this journey, there were several stopovers in the

Table 1 Autumn migration information for juvenile Chinese Egrets

\begin{tabular}{|c|c|c|c|c|c|c|c|c|}
\hline Id & Gender & Complete migration & Departure date & Arrival date & Migration route & $\begin{array}{l}\text { Migration } \\
\text { distance (km) }\end{array}$ & $\begin{array}{l}\text { Flight } \\
\text { speed } \\
(\mathrm{km} / \mathrm{h})\end{array}$ & $\begin{array}{l}\text { Max flight } \\
\text { speed } \\
(\mathrm{km} / \mathrm{h})\end{array}$ \\
\hline JE1813 & M & $\mathrm{N}$ & 2018/10/10 & - & Coastal & - & - & 65.0 \\
\hline JE1814 & $\mathrm{F}$ & Y & 2018/10/17 & $2018 / 10 / 22$ & Coastal & 4437.93 & 50.43 & 81.8 \\
\hline JE1815 & M & Y & 2018/10/06 & 2018/10/10 & Coastal & 4274.24 & 57.76 & 83.9 \\
\hline JE1816 & $\mathrm{F}$ & Signal lost & 2018/10/06 & - & Coastal & - & - & 74.6 \\
\hline JE1817 & $\mathrm{F}$ & $\mathrm{N}$ & 2018/10/10 & - & Coastal & - & - & 90.2 \\
\hline JE1818 & M & Y & 2018/10/17 & 2018/10/21 & Coastal & 3872.42 & 56.95 & 92.2 \\
\hline JE1819 & $F$ & $\mathrm{~N}$ & 2018/09/23 & - & Coastal & - & - & 115.2 \\
\hline JE1820 & $\mathrm{F}$ & $\mathrm{N}$ & 2018/10/16 & - & Coastal & - & - & 74.2 \\
\hline JE1821 & $M$ & $\mathrm{~N}$ & 2018/10/17 & - & Inland & - & - & 79.7 \\
\hline JE1822 & $\mathrm{F}$ & Y & 2018/10/06 & 2018/10/08 & Oceanic & 3305.44 & 55.09 & 89.0 \\
\hline JE1823 & $M$ & Y & 2018/10/17 & $2018 / 10 / 22$ & Coastal & 3950.17 & 56.43 & 96.9 \\
\hline JE1824 & $M$ & $\mathrm{~N}$ & 2018/10/17 & - & Inland & - & - & 74.2 \\
\hline JE1825 & $F$ & Y & 2018/09/30 & 2018/10/03 & Coastal & 4031.17 & 57.59 & 98.3 \\
\hline JE1826 & $M$ & $\mathrm{~N}$ & 2018/10/17 & - & Coastal & - & - & 83.2 \\
\hline JE1828 & $M$ & $\mathrm{~N}$ & $2018 / 10 / 26$ & - & Oceanic & - & - & 93.5 \\
\hline JE1829 & $M$ & $\mathrm{~N}$ & 2018/10/06 & - & Coastal & - & - & 115.5 \\
\hline JE1830 & $M$ & $\mathrm{~N}$ & 2018/10/16 & - & Coastal & - & - & 88.6 \\
\hline JE1831 & $M$ & $\mathrm{~N}$ & 2018/10/16 & - & Inland & - & - & 71.4 \\
\hline JE1832 & $\mathrm{F}$ & Y & 2018/10/06 & 2018/10/10 & Oceanic & 3368.40 & 54.33 & 116.8 \\
\hline JE1834 & $\mathrm{F}$ & Y & $2018 / 10 / 28$ & 2018/11/01 & Coastal & 3664.78 & 63.19 & 91.5 \\
\hline JE1835 & $\mathrm{F}$ & Signal lost & $2018 / 10 / 23$ & - & Coastal & - & - & 92.5 \\
\hline JE1837 & $\mathrm{F}$ & Y & $2018 / 10 / 26$ & 2018/10/29 & Coastal & 4358.56 & 62.27 & 106.6 \\
\hline JE1838 & $M$ & $\mathrm{~N}$ & 2018/10/26 & - & Inland & - & - & 87.7 \\
\hline JE1839 & $\mathrm{F}$ & $\mathrm{N}$ & 2018/10/01 & - & Inland & - & - & 76.9 \\
\hline JE1842 & $M$ & Y & 2018/10/10 & 2018/10/15 & Coastal & 4562.74 & 71.29 & 95.3 \\
\hline JE1844 & $F$ & Y & 2018/10/01 & 2018/10/05 & Coastal & 3451.76 & 49.31 & 100.4 \\
\hline JE1845 & $M$ & $\mathrm{~N}$ & 2018/11/16 & - & Coastal & - & - & 62.1 \\
\hline JE1847 & $M$ & Y & 2018/10/06 & 2018/10/10 & Coastal & 3696.93 & 56.01 & 91.7 \\
\hline JE1851 & $M$ & Signal lost & 2018/10/17 & - & Coastal & - & - & 79.9 \\
\hline JE1852 & $\mathrm{F}$ & Y & 2018/10/16 & $2018 / 10 / 22$ & Coastal & 4091.75 & 53.84 & 89.0 \\
\hline
\end{tabular}


coastal wetlands of China, including those in Shandong, Jiangsu, Shanghai, Zhejiang, Fujian, Taiwan, Guangdong, Guangxi, and Hainan.

The inland route of juvenile Chinese Egrets was via Chinese mainland to the wintering area. On this journey, their stopovers were mainly distributed in the freshwater wetlands of Chinese mainland, including those in Anhui, Jiangxi, Hunan, and Guangxi. Six juveniles (one female, five males) migrated via this route (Fig. 1). Two flew inland but stayed in Guangxi, China, which is not a reported wintering area for the Chinese Egret, and died or lost data there in late winter. The other four juveniles died during inland migration, with one staying near the Poyang Lake in Jiangxi Province, China, for 51 days.

The oceanic route of juvenile Chinese Egrets was a migration route in which juveniles flew over the Pacific Ocean to the wintering area. Three juveniles (two females, one male) migrated via this route, with two females directly arriving in the wintering area without a stopover. These two females flew over $3305.44 \mathrm{~km}$ in $56 \mathrm{~h}$ and $3368.40 \mathrm{~km}$ in $62 \mathrm{~h}$ across the Pacific Ocean. The male migrating via the oceanic route flew along the Korean Peninsula and Japan, and passed over the western Pacific Ocean but unfortunately died at a stopover site in Taiwan.

\section{Migration movements}

The juvenile Chinese Egrets began their migration journeys between September 23rd and November 16th, with a departure peak occurring October 16th to 17th among eight males. Unlike males, females mostly embarked on different dates and most of them $(N=11$, approximately 73\%) left before October 16th (Table 1). These juveniles arrived in wintering areas between October 3rd and November 1st.

Juvenile Chinese Egrets mainly migrated during the night. The total flight time for all juveniles $(N=30)$ was $622 \mathrm{~h}(79.85 \%)$ during the night from 6:00 p.m. to 6:00 a.m. and $157 \mathrm{~h}(20.15 \%)$ during the day. The complete migration duration of 13 juveniles averaged $5.08 \pm 1.04$ days, with the shortest time being approximately 3 days without stopover, and the longest duration was 7 days with 4 stopovers. There was no significant difference in migration duration between males $(N=5$, $5.40 \pm 0.55$ days $)$ and females $(N=8,4.88 \pm 1.25$ days $)$ $(p>0.05)$. The stopover duration of these 13 juveniles averaged $23.08 \pm 19.28 \mathrm{~h}$ during the complete migration, ranging from 6 to $66 \mathrm{~h}$. The flight speed during the complete migration averaged $57.27 \pm 5.73 \mathrm{~km} / \mathrm{h}$, and the maximum speed reached $116.8 \mathrm{~km} / \mathrm{h}$. The migratory distance of these juvenile egrets during the complete migration averaged $3928.18 \pm 414.27 \mathrm{~km}$, ranging from 3305.44 to $4562.74 \mathrm{~km}$. There was

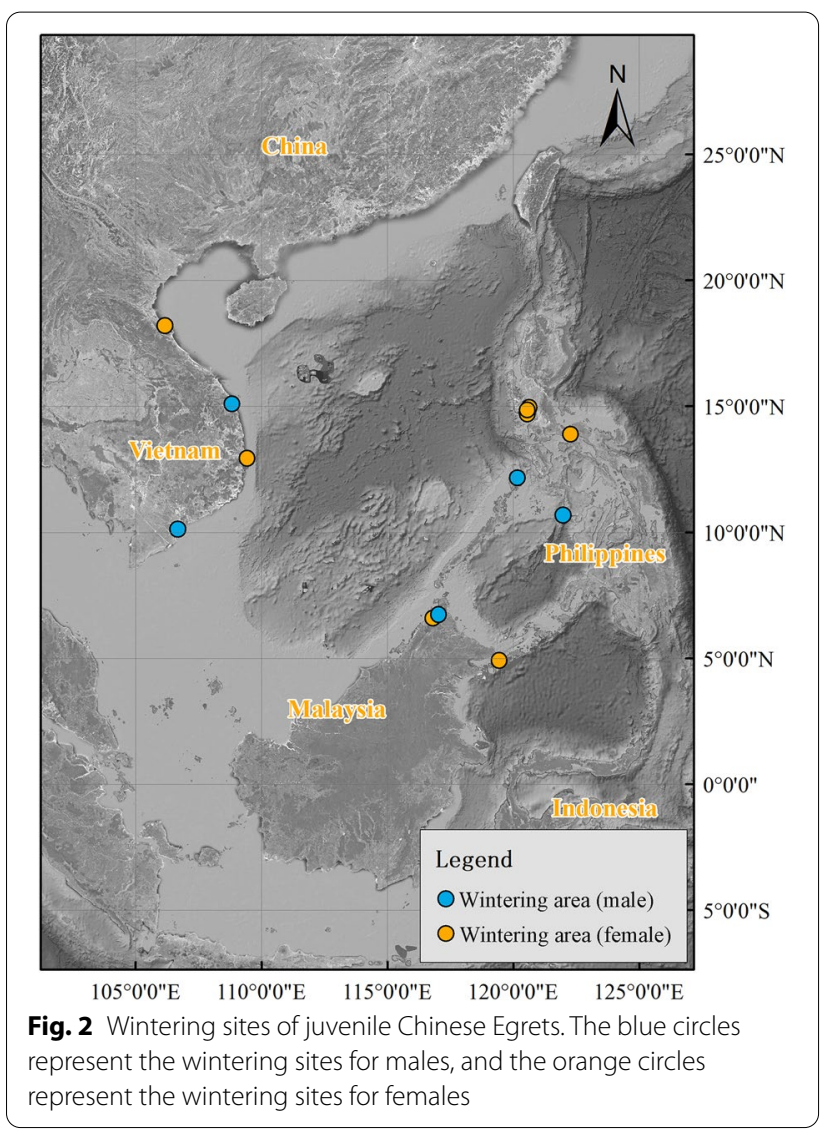

no significant difference in migration distance between males $(4071.30 \pm 345.35 \mathrm{~km})$ and females $(3838.72 \pm 449.75 \mathrm{~km})(p>0.05)$.

\section{Wintering areas}

Our data map (Fig. 2) showed that five (three females, two males) juvenile Chinese Egrets arrived and wintered in the Philippines, four (two females, two males) arrived and wintered in Vietnam, and three (two females, one male) arrived and wintered in Malaysia. Two juveniles (one female, one male) stayed in Guangxi in China and died or lost data there in late winter, suggesting that Guangxi might be a newly recorded wintering area of the Chinese Egret. This observation needs to be further confirmed with more evidence, such as adult wintering records or juvenile survival through the whole wintering period. The wintering area covered $4.9127^{\circ} \mathrm{N}$ to $18.75929^{\circ} \mathrm{N}$ latitude and $105.76315^{\circ} \mathrm{E}$ to $122.28246^{\circ} \mathrm{E}$ longitude (Table 2). Of these juveniles, 12 individuals died while staying in their wintering areas, one (JE1815) lost its signal in January 2019, and only one successfully started its spring migration on June 2020 after staying in the Philippines for 606 days. 
Table 2 Wintering areas of juvenile Chinese Egrets

\begin{tabular}{|c|c|c|c|c|c|c|c|}
\hline Id & Gender & Country & $\begin{array}{l}\text { First-arrival } \\
\text { longitude }\left({ }^{\circ} \mathrm{E}\right)\end{array}$ & $\begin{array}{l}\text { First-arrival } \\
\text { latitude }\left({ }^{\circ} \mathrm{N}\right)\end{array}$ & $\begin{array}{l}\text { Longitude } \\
\left({ }^{\circ} \mathrm{E}\right)\end{array}$ & $\begin{array}{l}\text { Latitude } \\
\left({ }^{\circ} \mathrm{N}\right)\end{array}$ & Survival time in wintering area (day) \\
\hline JE1814 & $F$ & Malaysia & 120.60222 & 13.49441 & 119.44778 & 4.9127 & 5 \\
\hline JE1815 & M & Malaysia & 116.68037 & 6.86859 & 116.65495 & 6.87045 & Data lost in 5-5-2019 (207) \\
\hline JE1818 & M & Philippines & 120.17426 & 12.15116 & 119.87864 & 12.40801 & 5 \\
\hline JE1822 & $\mathrm{F}$ & Philippines & 122.28246 & 13.88808 & 122.28246 & 13.88808 & 23 \\
\hline JE1823 & M & Philippines & 120.69018 & 14.95215 & 121.96769 & 10.71733 & 9 \\
\hline JE1825 & F & Vietnam & 109.42664 & 12.92982 & 109.42664 & 12.92982 & 35 \\
\hline JE1832 & $\mathrm{F}$ & Philippines & 121.22903 & 18.56443 & 120.20459 & 13.80685 & 484 \\
\hline JE1834 & $\mathrm{F}$ & Vietnam & 108.48739 & 15.68706 & data lost & Data lost & Data lost \\
\hline JE1837 & F & Malaysia & 116.65784 & 6.98118 & 116.65784 & 6.87118 & 17 \\
\hline JE1842 & M & Vietnam & 109.07333 & 13.89422 & 106.67048 & 10.12373 & 13 \\
\hline JE1844 & $\mathrm{F}$ & Philippines & 120.54535 & 14.79499 & 120.61732 & 13.96882 & 606 (spring migration in 6-1-2020) \\
\hline JE1847 & M & Vietnam & 109.01347 & 14.89908 & 108.87021 & 15.07266 & 10 \\
\hline JE1852 & $\mathrm{F}$ & Vietnam & 105.79143 & 18.71875 & 105.76315 & 18.75929 & 10 \\
\hline
\end{tabular}

\section{Discussion}

This GPS tracking study showed that the autumn migration of juvenile Chinese Egrets migrated southward via three routes: coastal, oceanic, and inland. The oceanic route was the first to be reported for this egret, and the coastal and inland routes were consistent with previous findings of studies tracking juvenile Chinese Egrets in China (Zhang et al. 2018). The oceanic route had a shorter migration distance (3336.92 $\mathrm{km}$ on average) and migration duration $(59.00 \mathrm{~h})$ than the coastal route (4035.68 $\mathrm{km}$ and $70.55 \mathrm{~h}$, respectively). The coastal migration route was the most important for juvenile Chinese Egrets, as it was popular for autumn migration, suggesting that coastal wetlands are critical habitats for the conservation of the vulnerable Chinese Egret. The inland route, such as that used by one individual that stayed for 51 days in Poyang Lake in Chinese mainland, suggests that juvenile egrets might consume prey in freshwater habitats during the autumn migration. Previous nestling diet analyses on offshore breeding islands in southern China indicated that the nestlings depended on prey that only occurred in coastal wetlands (Fang et al. 2011).

Our tracking data indicated that juvenile Chinese Egrets departed southward in autumn from the vicinity of their natal island to their wintering areas, the Philippines, Vietnam, and Malaysia, after a premigratory stage in early summer. This migration information is highly consistent with the typical pattern of autumn migration in other juvenile ardeid birds, such as Reddish Egrets (Egretta rufescens) (Geary et al. 2015) and Purple Herons (Ardea purpurea) (Jourdain et al. 2008). However, there are some differences in the movement traits of ardeid species. The average migratory distance of juvenile Chinese Egrets $(3928.18 \pm 414.27 \mathrm{~km})$ was longer than that of juvenile Reddish Egrets (1140.41 $\pm 179.16 \mathrm{~km}$ ) (Geary et al. 2015), and the average flight speed of juvenile Chinese Egrets $(57.27 \pm 5.73 \mathrm{~km} / \mathrm{h})$ was faster than that of juvenile Purple Herons (approximately $40 \mathrm{~km} / \mathrm{h}$ ) and juvenile Reddish Egrets $(4.87 \mathrm{~km} /$ day) (Jourdain et al. 2008; Geary et al. 2015). Analyzing consistency and plasticity in migratory traits between short- and longdistance migrants within the same species is essential to understand the evolution and ontogeny of migratory strategies (Monti et al. 2018). The oceanic route of juvenile Chinese Egrets had a shorter migration distance (3336.92 km on average), fewer stopover (0), and slower flight speed $(54.71 \mathrm{~km} / \mathrm{h})$ when compared to those of the coastal route $(4035.68 \mathrm{~km} ; 1.5$; and $57.73 \mathrm{~km} / \mathrm{h}$, respectively). A study on short- and long-distance migratory Ospreys (Pandion haliaetus) showed that short-distance migration birds had shorter migratory distances, lower stopover use, and a faster flight speed when compared to long-distance migratory birds, suggesting that migration distance affects stopover use but not flight speed and that the lower flight speed is due to higher stopover use (Monti et al. 2018). Our data support the conclusion that migration distance affects stopover use when juvenile Chinese Egrets use a relatively direct oceanic route across the Pacific Ocean without stopovers but do not correspond with the suggestion that higher stopover use reduces flight speed.

The mortalities of tracked juvenile Chinese Egrets were $23.08,38.46$, and $23.08 \%$ in the stages of premigration, migration and wintering, respectively. The associated high mortality indicates that autumn migration is a more critical time affecting the survival of juvenile Chinese Egrets than both the premigration and wintering periods. The first autumn migration is a crucial time for 
juveniles because of the combination of their relatively low mobility and inexperience. Juveniles may experience high costs associated with their relatively low flight performance because of their inexperience when using thermals (on land) or choosing favorable air currents (Mitchell et al. 2015). They may spend more time at stopover sites to refuel than older individuals due to their low foraging efficiency (Riotte-Lambert and Weimerskirch 2013). Moreover, juveniles may be more likely to interact naively with predators or venture into suboptimal habitats, decreasing their probability of obtaining adequate refuel and/or survival (Geary et al. 2015). In addition, during migration, the mortalities of our tracked juveniles along the coastal, oceanic, and inland route were 33.33, 33.33 , and $83.33 \%$, respectively. The juveniles successfully finished migration had significantly lower stopover use $(N=13 ; 1.38 \pm 1.04)$ than the unsuccessful individuals $(N=14 ; 3.86 \pm 2.60)(p<0.01)$, suggesting that low stopover use may reduce mortality during autumn migration. When migrants increase their use of stopovers during the migratory period, they may experience a longer time over which to encounter harsh environmental conditions, leading to death.

Our data support that the Chinese Egret is one of the key species making use of the East Asian-Australasian Flyway (EAAFP 2020). The migratory routes taken by juvenile Chinese Egrets stretch from China, southward through East Asia to wintering areas in Southeast Asia including the Philippines, Malaysia, and Vietnam, which could be identified as a part of the East Asian-Australasian Flyway (EAAFP 2020). During the migration journey, Chinese Egrets should rely on a system of healthy wetlands to rest and feed. The habitats along the flyway, ranging from important inland wetlands to coastal and offshore sites, are internationally important in supporting the vulnerable Chinese Egret. Among the three migratory routes used by juvenile Chinese Egrets, the coastal route was most often used, suggesting that coastal wetlands are particularly important for these birds. In the future, it is essential to identify and conserve a network of important wetlands used by the Chinese Egret throughout its migratory routes.

\section{Conclusions}

Juvenile Chinese Egrets were found to migrate southward via three migration routes, coastal, oceanic, and inland, winter in the coastal wetlands of Southeast Asia, including the Philippines, Vietnam, and Malaysia, and begin their spring migration in the third year, which confirms that the Chinese Egret is one of the key species using the East Asian-Australasian Flyway. Among these routes, the oceanic route is newly reported in this study. Moreover, the coastal route is most often used by juveniles during autumn migration, suggesting that coastal wetlands are particularly important. The inland route used by some juveniles indicates that they may rely on freshwater wetland habitats. Our novel autumn migration data collected for the Chinese Egret suggest that international cooperation is important to conserve this vulnerable egret and the wetland habitats on which it depends. These results provide a fundamental basis for further studies to develop conservation plans for this vulnerable species.

\section{Acknowledgements}

We thank Jingtao Liu, Danxia Xia, Ying Yin, and Yihuang Chen who helped attach transmitters and collect samples in field. We also thank Yuwei Huang, Haoran Luo, and Wei Xu for assistance in laboratory work of this study.

\section{Authors' contributions}

ZH designed and performed the experiments, completed the analyses, and wrote the manuscript; $X C$ and WF conceived, directed, and coordinated this study, helped with writing, and revised the manuscript. XZ collected some samples, assisted with analyses and lab work. $\mathrm{HZ}$ assisted with bird capture and transmitter attachment in field. All authors read and approved the final manuscript.

\section{Funding}

This research was supported by the National Natural Science Foundation of China (Grant Nos. 42076107, 41676123, and 41476113). The funder had no role in the data collection and analysis, publish decision, or manuscript preparation of this study.

\section{Availability of data and materials}

The datasets used in the present study are available from the corresponding author on reasonable request.

\section{Declarations}

Ethical approval and consent to participate

The license for this research in the study site was issued by the Forestry and Grassland Administration, Liaoning Province, China (Permission Number: 201810). This research and all procedures were approved by the Animal Ethics Committee in Xiamen University, China. Field work was conducted in the evening, and visits to a breeding colony were restricted to a maximum of two hours per day.

\section{Consent for publication}

Not applicable.

\section{Competing interests}

The authors declare that they have no competing interests.

\section{Author details}

${ }^{1}$ Key Laboratory of the Ministry of Education for Coastal and Wetland Ecosystems, College of the Environment and Ecology, Xiamen University, Xiamen 361102, China. ${ }^{2}$ Liaoning Provincial Center of Wildlife Conservation and Epidemic Disease Surveillance, Dalian 116013, China.

Received: 30 December 2020 Accepted: 14 October 2021

Published online: 18 November 2021

\author{
References \\ Alerstam T, Hedenström A, Åkesson S. Long-distance migration: evolution and \\ determinants. Oikos. 2003;103:247-60. \\ Alonso H, Correia RA, Marques AT, Palmeirim JM, Moreira F, Silva JP. Male \\ post-breeding movements and stopover habitat selection of an \\ endangered short-distance migrant, the Little Bustard Tetrax tetrax. Ibis. \\ 2020;162:279-92.
}


BirdLife International. Species factsheet: Egretta eulophotes. 2020. http://www. birdlife.org. Accessed 07 Nov 2020

Dai Y, Lin Q, Fang W, Zhou X, Chen X. Noninvasive and nondestructive sampling for avian microsatellite genotyping: a case study on the vulnerable Chinese Egret (Egretta eulophotes). Avian Res. 2015;6:24.

EAAFP. Shorebird working group-key species. 2020. https://www.eaaflyway. net/. Accessed 07 Nov 2020

Fang W, Lin Q, Chen X, Lin J. Nestling diet of the vulnerable Chinese Egret on offshore islands in southern China. Waterbirds. 2011:34:247-52.

Geary B, Green CM, Ballard BM. Movements and survival of juvenile reddish egrets Egretta rufescens on the Gulf of Mexico coast. Endanger Species Res. 2015;28:123-33.

Google Inc. Google Earth Pro. computer program.; 2013.

Hadjikyriakou TG, Nwankwo EC, Virani MZ, Kirschel ANG. Habitat availability influences migration speed, refueling patterns and seasonal flyways of a fly-and-forage migrant. Mov Ecol. 2020;8:10.

Hewson CM, Thorup K, Pearce-Higgins JW, Atkinson PW. Population decline is linked to migration route in the Common Cuckoo. Nat Commun. 2016;7:12296.

Huang X, Zhou X, Lin Q, Fang W, Chen X. PCR-RFLP technique for species identification of molted feathers in six species of co-occurring Ardeids. Conserv Genet Resour. 2013;5:817-9.

Huschle G, Toepfer JE, Douglas DC. Migration and wintering areas of American Bitterns (Botaurus lentiginosus) that summer in central North America as determined by satellite and radio telemetry, 1998-2003. Waterbirds. 2013;36:300-9.

Jourdain E, Gauthier-Clerc M, Kayser Y, Lafaye M, Sabatier P. Satellite-tracking migrating juvenile Purple Herons Ardea purpurea from the Camargue area. France Ardea. 2008;96:121-4

Klaassen RHG, Strandberg R, Hake M, Olofsson P, Tøttrup AP, Alerstam T. Loop migration in adult marsh harriers Circus aeruginosus, as revealed by satellite telemetry. J Avian Biol. 2010;41:200-7.

Klaassen RHG, Hake M, Strandberg R, Koks BJ, Trierweiler C, Exo KM, et al. When and where does mortality occur in migratory birds? Direct evidence from long-term satellite tracking of raptors. J Anim Ecol. 2014;83:176-84.

Lei W, Fang W, Zhou X, Lin Q, Chen X. Population genetic diversity and geographical differentiation of MHC class II DAB genes in the vulnerable Chinese egret (Egretta eulophotes). Conserv Genet. 2016;17:1459-68.

Li X, Wang X, Fang L, Batbayar N, Natsagdorj T, Davaasuren B, et al. Annual migratory patterns of Far East Greylag Geese (Anser anser rubrirostris) revealed by GPS tracking. Integr Zool. 2020;15:213-23.

McKinnon EA, Fraser KC, Stanley CQ, Stutchbury BJM. Tracking from the tropics reveals behaviour of juvenile songbirds on their first spring migration. PLOS ONE. 2014;9:e105605.

Mellone U, López-López P, Limiñana R, Piasevoli G, Urios V. The trans-equatorial loop migration system of Eleonora's falcon: differences in migration patterns between age classes, regions and seasons. J Avian Biol. 2013:44:417-26

Meyburg BU, Bergmanis U, Langgemach T, Graszynski K, Hinz A, Börner I, et al. Orientation of native versus translocated juvenile lesser spotted eagles (Clanga pomarina) on the first autumn migration. J Exp Biol. 2017;220:2765-76.
Mi C, Møller AP, Guo Y. Annual spatio-temporal migration patterns of Hooded Cranes wintering in Izumi based on satellite tracking and their implications for conservation. Avian Res. 2018;9:23.

Mitchell GW, Woodworth BK, Taylor PD, Norris DR. Automated telemetry reveals age specific differences in flight duration and speed are driven by wind conditions in a migratory songbird. Mov Ecol. 2015;3:19.

Monti F, Grémillet D, Sforzi A, Sammuri G, Dominici JM, Bagur RT, et al. Migration and wintering strategies in vulnerable Mediterranean Osprey populations. Ibis. 2018;160:554-67.

Newton I. The migration ecology of birds. London: Academic Press; 2008.

Oppel S, Dobrev V, Arkumarev V, Saravia V, Bounas A, Kret E, et al. High juvenile mortality during migration in a declining population of a long-distance migratory raptor. Ibis. 2015;157:545-57.

Page GW, Warnock N, Tibbitts TL, Jorgensen D, Hartman CA, Stenzel LE. Annual migratory patterns of Long-billed Curlews in the American West. Condor. 2014;116:50-61.

R Core Team. R: a language and environment for statistical computing. Vienna: R Foundation for Statistical Computing; 2018.

Rappole JH. The avian migrant. New York: Columbia University Press; 2013.

Riotte-Lambert L, Weimerskirch $\mathrm{H}$. Do naive juvenile seabirds forage differently from adults? Proc R Soc B. 2013;280:20131434.

Rotics S, Kaatz M, ResheffYS, Turjeman SF, Zurell D, Sapir N, et al. The challenges of the first migration: movement and behaviour of juvenile vs. adult white storks with insights regarding juvenile mortality. J Anim Ecol. 2016;85:938-47.

Sergio F, Tanferna A, de Stephanis R, Jiménez LL, Blas J, Tavecchia G, et al. Individual improvements and selective mortality shape lifelong migratory performance. Nature. 2014;515:410-3.

Sergio F, Tanferna A, Blas J, Blanco G, Hiraldo F. Reliable methods for identifying animal deaths in GPS- and satellite-tracking data: review, testing, and calibration. J Appl Ecol. 2019;56:562-72.

Strandberg R, Klaassen RHG, Hake M, Alerstam T. How hazardous is the Sahara Desert crossing for migratory birds? Indications from satellite tracking of raptors. Biol Lett. 2010;6:297-300.

Vega ML, Willemoes M, Thomson RL, Tolvanen J, Rutila J, Samaš P, et al. Firsttime migration in juvenile common cuckoos documented by satellite tracking. PLoS ONE. 2016;11:e0168940.

Wang Z, Zhou X, Lin Q, Fang W, Chen X. Characterization, polymorphism and selection of major histocompatibility complex (MHC) DAB genes in vulnerable Chinese egret (Egretta eulophotes). PLoS ONE. 2013;8:e74185.

Yoda K, Yamamoto T, Suzuki H, Matsumoto S, Müller M, Yamamoto M. Compass orientation drives naïve pelagic seabirds to cross mountain ranges. Curr Biol. 2017;27:R1152-3.

Zhang H, Zhang F, Zhang Y. Study on the migration of subadult Egretta eulophotes by statellite tracking at Fantuozi island, Dalian City. Sichuan J Zool. 2018:37:519-24 (In Chinese).

Zhou X, Fang W, Chen X. Mitochondrial DNA diversity of the vulnerable Chinese Egret (Egretta eulophotes) from China. J Ornithol. 2010;151:409-14.

Ready to submit your research? Choose BMC and benefit from:

- fast, convenient online submission

- thorough peer review by experienced researchers in your field

- rapid publication on acceptance

- support for research data, including large and complex data types

- gold Open Access which fosters wider collaboration and increased citations

- maximum visibility for your research: over $100 \mathrm{M}$ website views per year

At BMC, research is always in progress.

Learn more biomedcentral.com/submissions 